\title{
Development of neutralization antibodies against highly pathogenic H5N1 avian influenza virus using ostrich (Struthio camelus) yolk
}

\author{
KAZUHIDE ADACHI ${ }^{1}$, EKOWATI HANDHARYANI ${ }^{3}$, DWI KESUMA SARI ${ }^{3}$, KENTARO TAKAMA ${ }^{1}$, \\ KEIKO FUKUDA $^{1}$, ISAKO ENDO ${ }^{1}$, RYOHEI YAMAMOTO ${ }^{2}$, MASAKI SAWA ${ }^{2}$, MASARU TANAKA ${ }^{2}$, \\ ITSURO KONISHI $^{2}$ and YASUHIRO TSUKAMOTO ${ }^{1}$
}

\begin{abstract}
${ }^{1}$ Laboratory of Veterinary Anatomy, Graduate School of Biology and Environmental Sciences, Osaka Prefecture University, Gakuencho 1-1, Sakai, Osaka 599-8531; ${ }^{2}$ Ostrich Breeding Farm 'Ostrich-Kobe', Kande-Housei, Nishiku, Kobe-City, Hyogo 651-2321, Japan; ${ }^{3}$ Departments of Veterinary Pathology and Veterinary Anatomy, Faculty of Veterinary Medicine, Bogor Agricultural University, Jl. Agatis Kampus IPB, Darmaga, Bogor 16680, Indonesia
\end{abstract}

Received December 3, 2007; Accepted January 4, 2008

\begin{abstract}
The rapid outbreak of the highly pathogenic H5N1 avian influenza virus and its transmission to humans have induced world-wide fears of a new influenza pandemic. The most effective method for the reduction of the impact of such a pandemic would be prophylaxis with a safe and effective vaccine, as well as anti-viral materials. In this study, we generated the specific antibodies 'immunoglobulin yolk (IgY)' from ostrich eggs immunized with a full-length glycosylated recombinant H5 protein of the strain H5N1/Vietnam/1203/ 2004. Using this simple method, abundant specific antibody (about $200 \mathrm{~g}$ ) against H5 was successfully produced by one female ostrich in a year. The IgY from the immunized ostrich eggs had strong reactivity to the H5N1 virus as well as to H5 proteins. Furthermore, the antibodies strongly inhibited cytopathic effects in MDCK cells and prevented the death of an embryonated chick after a viral inoculation, indicating strong neutralization activity against H5N1 infections. These findings suggest that the neutralization antibody produced by the H5-immunized ostrich is suitable for industrial purposes, such as the development of antibody-binding filters, which can be applied to a mask or to air-conditioners to prevent the influenza pandemic through antigen-antibody reactions. Of note, the mortality rate of chicks inoculated with the H5N1 virus was dramatically decreased with antibody injection. This indicates that ostrich $\operatorname{IgY}$ is a potentially effective therapeutic modality for H5N1 infection.
\end{abstract}

Correspondence to: Dr Yasuhiro Tsukamoto, Laboratory of Veterinary Anatomy, Graduate School of Biology and Environmental Sciences, Osaka Prefecture University, Gakuencho 1-1, Sakai, Osaka 599-8531, Japan

E-mail: ytsuka@vet.osakafu-u.ac.jp

Key words: antibody, influenza virus, H5N1, pandemic, ostrich, IgY

\section{Introduction}

Influenza is recognized as a zoonotic disease, with the most commonly affected animals being humans, pigs, horses and species of aquatic birds (1). Influenza viruses belong to the family Orthomyxoviridae and are divided into three types, A, $\mathrm{B}$ and $\mathrm{C}$. A type viruses are responsible for major disease problems in humans as well as in avian species (2-4) and are further classified into subtypes on the basis of their antigenic properties, including hemagglutinin (HA) and neuraminidase on the viral particle. There is world-wide concern over the possibility of a new influenza pandemic, especially since the appearance of the highly pathogenic avian influenza viruses H5N1, which have the capacity for lethal infection in man. Since 1997, over 200 people have been infected with H5N1, resulting in a mortality rate of over $50 \%$ (5). In addition, the H5N1 virus has been able to spread by means of domestic and wild birds from Hong Kong, where it was first detected, across Asia, Africa, and into northern Europe. Should the H5N1 virus develop the ability to spread efficiently from man to man, there would be a high risk of worldwide pandemic causing considerable mortality and economic disruption (6). It has been discussed that the most effective method to reduce the impact of a pandemic would be prophylaxis with a safe and effective vaccine $(6,7)$, as well as anti-viral materials including masks or facial tissues (8).

Antibodies are increasingly used for research, diagnosis and therapeutic purposes. However, antibodies from experimental mammals, including mice and rabbits, are not adapted for industrial use because of their high production cost. Of late, the avian egg as an antibody source has proven to be attractive for the non-invasive production of antibodies with applications in research, diagnosis and immunotherapy (9-11). In addition, the production of avian antibodies offers many advantages over mammalian antibodies in terms of their specificity for antigens, production cost and uses (9).

The predominant class of immunoglobulin in birds is immunoglobulin yolk ( $\operatorname{IgY}$ ), which is transferred from the serum to the yolk to confer passive immunity to the embryo (12). Although the IgY and IgG of mammals are functionally 
equivalent, they differ with respect to certain physicochemical properties (13).

Recently, we developed a convenient method for the massproduction of antibodies using the female ostrich (Struthio camelus). The ostrich grows to up to $250 \mathrm{~cm}$ in height and $160 \mathrm{~kg}$ in weight, and has a life span of about 60 years. Its eggs weigh about $1.5 \mathrm{~kg}$ and are 30 -fold bigger than chicken eggs. They can lay one hundred eggs every year. We can purify about $2 \mathrm{~g}$ of IgY per ostrich egg. Accordingly, about $200 \mathrm{~g}$ of $\mathrm{IgY}$ is obtained from only one ostrich in the course of a year. Recent developments in breeding have permitted low-cost egg production from the ostrich, because they can be fed the factory waste from bean sprout production. Accordingly, we strongly believe that the ostrich egg may provide an excellent source of antibody for industrial purposes (14).

In the present study, we tried to produce antibodies against $\mathrm{H} 5 \mathrm{~N} 1$ from ostrich eggs. The HA proteins of the influenza viruses were considered to be suitable antigens for the immunization of the ostrich for the following reasons: i) influenza virus entry is mediated by the receptor binding domain of HA, and adaptation of avian viruses to humans is associated with HA specificity, and ii) the blockage of HA antigens leads to inactivation of the viral infection to host cells. We herein show that a high amount of neutralizing antibody against H5N1 was generated by the ostrich using a simple and economical method, which may lead to the development of anti-viral materials against an influenza pandemic.

\section{Materials and methods}

Generation of antibodies against influenza virus HA antigens. A mixture of HA antigens from vaccine strains of the human influenza virus (H1N1/NewCaledonia/20/99, H3N2/Hiroshima/ 52/2005 and B/Malaysia) (The Kitasato Institute Research Center for Biologicals, Japan) were used as antigens for the immunization of the ostrich, as well as $\mathrm{H} 5$ recombinant protein (rH5) purified from insect cells transfected with baculovirus vector inserting H5 gene of H5N1/Vietman/1203/2004 (Protein Sciences, USA).

The laying ostriches were immunized intra-muscularly in the lumbar region at multiple sites with the mixture of HA (30 $\mu \mathrm{g} /$ bird) or rH5 (50 $\mu \mathrm{g} /$ bird) emulsified in Freund's complete adjuvant (FCA). The boosters were administered every other week with both the antigens in Freund's incomplete adjuvant (FIA). Eggs were collected daily from the initial immune day. The yolk was separated from the albumin using egg yolk separator, the volume of the yolk was recorded and it was later stored at $-20^{\circ} \mathrm{C}$. Serum samples were also collected every week and stored at $-20^{\circ} \mathrm{C}$.

The yolk was separated from the albumin of the eggs and diluted to 5-fold with TBS-buffer $[0.02 \mathrm{M}$ Tris/ $\mathrm{HCl}$ (pH 7.5), $0.15 \mathrm{M} \mathrm{NaCl}$, increased 1- to 10-fold with $30 \%$ dextran sulfate in TBS and 2- to 3-fold with $2.5 \mathrm{M} \mathrm{CaCl}_{2}$ in TBS, then stored at $4^{\circ} \mathrm{C}$ for at least $4 \mathrm{~h}$. The supernatant containing IgY was collected by centrifugation $\left(10000 \mathrm{x}\right.$ g at $4^{\circ} \mathrm{C}$ for $15 \mathrm{~min}$ ) and precipitated with $45 \%$ saturated ammonium sulfate. The solution was centrifuged again at $10000 \mathrm{x}$ g at $4^{\circ} \mathrm{C}$ for $15 \mathrm{~min}$. The precipitate was then re-dissolved in TBS and dialyzed against PBS. Finally, the purified antibody solutions were verified by $10 \%$ SDS-PAGE under non-reducing or reducing conditions and stained with Coomassie Brilliant Blue (CBB).

Generation of rabbit polyclonal antibodies against ostrich $\operatorname{Ig} Y$. An experimental rabbit (Japanese-White) was immunized subcutaneously in the lumbar region at multiple sites with purified ostrich $\operatorname{IgY}(50 \mu \mathrm{g} /$ body $)$ emulsified in FCA. The boosters were given every other week with the same antigen in FIA. At the hyper-immunized stage, confirmed by ELISA, the serum was collected and the $\operatorname{IgG}$ purified with protein $\mathrm{G}$ as a routine procedure. The purified antibody fractions were verified by $10 \%$ SDS-PAGE under non-reducing conditions and stained with CBB. Finally, the purified IgG was conjugated with horseradish peroxidase (HRP) or FITC using the appropriate labeling kits (Dojin, Japan), then used as a secondary antibody (14).

Western blot analysis. $\mathrm{rH} 5$ proteins were separated with $10 \%$ SDS-PAGE in reducing conditions and electroblotted onto a nitrocellulose membrane (Bio-Rad). The membrane was air dried for 5-10 min, then blocked with blocking reagent (2\% skim-milk in PBS) at room temperature for $1 \mathrm{~h}$. After washing with a washing buffer (0.01 M PBS, pH 7.4 with $0.05 \%$ Tween-20), the membrane was incubated with the ostrich IgY against rH5 (1:4000) in the same blocking buffer at room temperature for $1 \mathrm{~h}$ on a horizontal shaker. Next, the membrane was washed and incubated with 1:5000 dilutions in blocking buffer of HRP-conjugated rabbit IgG against ostrich IgY at room temperature for $1 \mathrm{~h}$. After thorough washing, the membrane was placed in peroxidase chromogenic substrate solution (0.01 M PBS, pH 7.4 with $0.05 \%$ diaminobenzidine and $0.03 \%$ $\mathrm{H}_{2} \mathrm{O}_{2}$ ) for $5 \mathrm{~min}$, then immersed in excess distilled water to stop the color development. Finally, the Western blot membrane was digitally recorded using a gel documentation system (Fujifilm, Japan).

Enzyme linked immunosorbant assay (ELISA) using ostrich $\operatorname{Ig} Y$. Each well of polystyrene ELISA plates (Sumitomo Bakelite, Japan) was coated with $0.2 \mu \mathrm{g}$ HA antigens or rH5 protein in phosphate-buffered saline (PBS) and the plate was incubated overnight at $4^{\circ} \mathrm{C}$. Each of the following incubation steps were preceded by washing the wells twice with PBS containing $0.05 \%$ Tween-20. The wells were blocked for nonspecific binding by the addition of a commercial blocking buffer (DS Pharma Biomedical, Japan) and were incubated at $37^{\circ} \mathrm{C}$ for $2 \mathrm{~h}$. The serial dilutions of purified $\operatorname{IgY}$ were added vertically to the wells and kept for incubation at $37^{\circ} \mathrm{C}$ for $1 \mathrm{~h}$. HRP-conjugated rabbit IgG diluted (1:5000) in PBS was dispensed into each well. The plate was incubated for $1 \mathrm{~h}$ at $37^{\circ} \mathrm{C}$. Later, a substrate buffer containing TMB (Sumitomo Bakelite) was added to each well and kept for incubation at $37^{\circ} \mathrm{C}$ for $15 \mathrm{~min}$. The reaction was terminated by the addition of a stopping reagent (1.25 M sulfuric acid). The absorbance was recorded at $450 \mathrm{~nm}$ using the ELISA plate reader (DS Pharma Biomedical).

Viral infectivity $\left(\right.$ TCID $_{50}$ and EID $\left.{ }_{50}\right)$ assays. The H5N1/ Indonesian strain cloned from affected chickens was used throughout this study. The viral solutions were titered using a cell culture system (MDCK cells) onto 96-well microtiter 
plates or embryonated chick eggs by serial 10 -fold dilutions of the samples as a routine procedure.

Immunocytochemistry. MDCK cells seeded at a density of $5 \times 10^{4}$ on the well of the microtiter plate were infected with $\mathrm{H} 5 \mathrm{~N} 1$ virus $\left(1_{00 \mathrm{TCID}_{50}}\right)$ for $2-3$ days at $35^{\circ} \mathrm{C}$. The cultures showing cytopathic effect (CPE) were fixed with $10 \%$ buffered formalin for immunocytochemistry. After washing in PBS, the cells were incubated with the ostrich $\operatorname{Ig} Y$ $(1: 4000)$ against $\mathrm{HA}$ or $\mathrm{rH} 5$ for $1 \mathrm{~h}$ at $37^{\circ} \mathrm{C}$, and then incubated with FITC-conjugated rabbit $\operatorname{IgG}(1: 4000)$ against ostrich IgY following a sufficient number of washes in PBS. Finally, the specific signal was observed under fluorescence microscopy.

Neutralization assays for H5N1 infection. For the standard neutralization assay on cell cultures, serial dilutions in 2-fold step ostrich IgY were mixed at a ratio of $1: 1$ with $\mathrm{H} 5 \mathrm{~N} 1$ virus $\left(100 \mathrm{TCID}_{50}\right)$, incubated for $1 \mathrm{~h}$ at $37^{\circ} \mathrm{C}$, and then transferred to a microtiter plate with a MDCK monolayer. After 2-3 days incubation at $35^{\circ} \mathrm{C}$, the cultures were inspected for CPE. The neutralizing titer, expressed as the reciprocal of the $\operatorname{IgY}$ dilution at which virus growth is $50 \%$ inhibited, was calculated by the number of virus negative wells and the $\operatorname{IgY}$ dilution according to the report by Reed et al (15).

For the assay on the embryonated eggs, serial dilutions in a 4-fold step of ostrich IgY were mixed at a ratio of 1:1 with H5N1 virus $\left(100 \mathrm{EID}_{50}\right)$, incubated for $1 \mathrm{~h}$ at $37^{\circ} \mathrm{C}$, and injected into the allantoic cavity of the embryonic chicken eggs (10 days). After 2-3 days incubation at $35^{\circ} \mathrm{C}$, the embryos were inspected for their death. The neutralizing titer, expressed as the reciprocal of the $\mathrm{IgY}$ dilution at which virus growth is $50 \%$ inhibited, was calculated by the number of survivors and the IgY dilution.

Antibody injection into H5N1-infected chicks. At 10 days of age, the chicks were intra-nasally inoculated with $\mathrm{H} 5 \mathrm{~N} 1$ virus at a dose of $10^{7.8} \mathrm{TCID}_{50}$. They were injected intra-muscularly with PBS or preimmune $\operatorname{IgY}(10 \mu \mathrm{g} /$ bird $)$ or $\operatorname{IgY}$ against $\mathrm{rH} 5$ $(10 \mu \mathrm{g} / \mathrm{bird})$ at $1 \mathrm{~h}$ post-inoculation with $\mathrm{H} 5 \mathrm{~N} 1$. Then all chicks were boarded in individual cages in a BSL3 laboratory in Indonesia (Vaksindo Satwa Nusantara). At 5-days postviral-challenge, the number of dead chicks was counted and the results were expressed as the mean of dead birds in each experimental group (over 4 individuals in each group).

\section{Results}

Ostrich antibodies against HA antigen of influenza viruses. The IgY from the immunized ostrich with influenza virus HA antigens was purified from the yolk and visualized by SDSPAGE. The molecular weight of ostrich IgY is around $200 \mathrm{kDa}$ (heavy chain, $64 \mathrm{kDa}$; light chain, $28 \mathrm{kDa}$ ) and is heavier than that of rabbit IgG (Fig. 1). In a Western blot analysis, using a lysate of $\mathrm{H} 5 \mathrm{~N} 1$, the purified $\mathrm{IgY}$ from the rH5-immunized ostrich recognized the doublet bands of 45 and $25 \mathrm{kDa}$, corresponding to $\mathrm{HA}_{1}$ and $\mathrm{HA}_{2}$ of the $\mathrm{H} 5$ antigens, respectively (16) (Fig. 2). This indicated that the antibody against the H5 antigen of H5N1 was generated in the ostrich eggs.
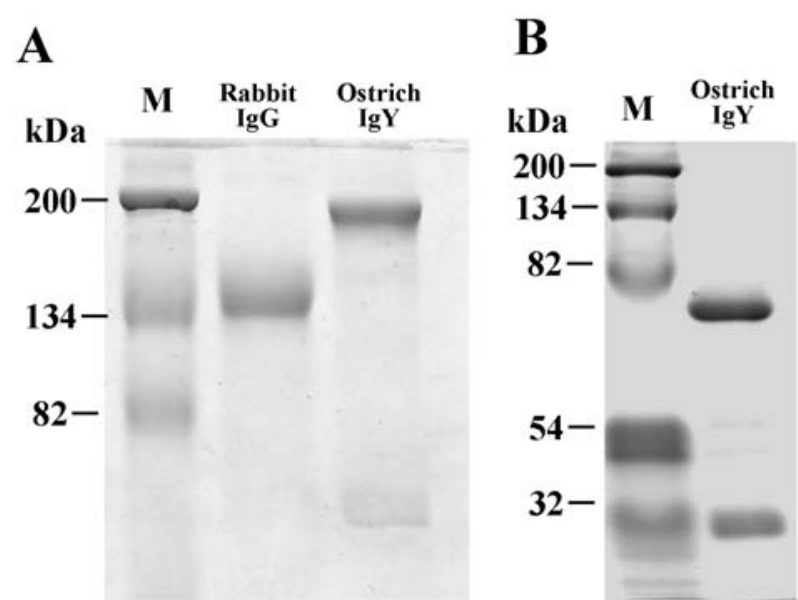

Figure 1. SDS-PAGE analysis of rabbit IgG and ostrich IgY. (A) Molecular weight of Rabbit IgG and ostrich IgY. Purified rabbit IgG and ostrich IgY were loaded under non-reducing conditions. The intact ostrich IgY is around $200 \mathrm{kDa}$ - heavier than rabbit IgG, which is about $150 \mathrm{kDa}$. A faint band under $82 \mathrm{kDa}$ in the ostrich $\mathrm{IgY}$ sample seems to be a heavy chain of $\mathrm{IgY}$. (B) The heavy and light chains of ostrich IgY. The samples were heated at $95^{\circ} \mathrm{C}$ for $2 \mathrm{~min}$ under reducing conditions. The doublet bands of 64 and $28 \mathrm{kDa}$ correspond to a heavy and light chain of $\mathrm{IgY}$, respectively. M, molecular weight marker.

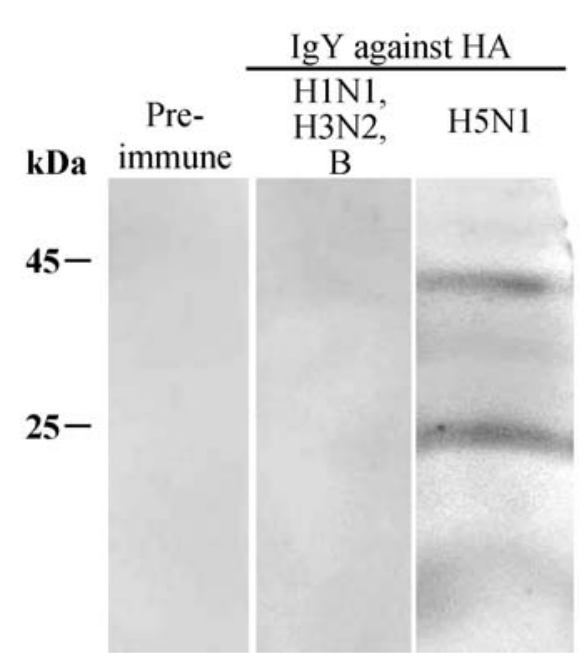

Figure 2. Western blot analysis of the HA antigen of the H5N1 virus. The reaction of ostrich antibodies to baculovirus-derived $\mathrm{H} 5$ recombinant protein (rH5) was examined by Western blotting. The HA (45 kDa) and HA2 $(25 \mathrm{kDa})$ proteins were strongly recognized by the $\mathrm{IgY}$ from $\mathrm{rH} 5$ immunized ostrich and slightly by HA (H1, H2, B) immunized ostrich. In contrast, no reaction was found by preimmune $\mathrm{IgY}$.

The IgY against each HA antigen was titered by ELISA in time course from the primary immunization day. The titers were increased dramatically in both serum and yolk from 2 weeks after the primary immunization time and reached the maximal peak at 8 weeks (data not shown). At the hyperimmune stage from 8 weeks on, about $2 \mathrm{~g}$ of $\mathrm{IgY}$ could be purified from one egg, indicating that it is possible to collect $200 \mathrm{~g}$ of IgY against the influenza virus from one female ostrich in one year. The ELISA titers of IgY against HA antigens are shown in Table I. The IgY from eggs immunized with HA-mixtures of antigens from the vaccine strains showed high reactivity to $\mathrm{H} 1 \mathrm{~N} 1, \mathrm{H} 3 \mathrm{~N} 2$ and $\mathrm{B}$ strains, but reacted 
Table I. ELISA titers of ostrich IgY against influenza viruses HA antigens.

\begin{tabular}{|c|c|c|c|c|c|}
\hline \multirow{2}{*}{$\begin{array}{l}\text { Antibodies against } \\
\text { indicated HA antigens }\end{array}$} & \multirow{2}{*}{$\begin{array}{l}\text { Concentration } \\
(\mathrm{mg} / \mathrm{ml})\end{array}$} & \multicolumn{4}{|c|}{ Reciprocal IgY titer against indicated influenza virus HA antigens } \\
\hline & & H1N3 & H3N2 & B & H5N1 \\
\hline $\mathrm{H} 1, \mathrm{H} 3, \mathrm{~B}$ & 2 & 102400 & 204800 & 102400 & 3200 \\
\hline rH5 & 2 & 800 & 1600 & 800 & 51200 \\
\hline
\end{tabular}

The IgY activities to each HA antigens of influenza viruses were measured by ELISA. The antibody titer was defined as the reciprocal of the highest IgY dilutions that produced an ELISA signal twice as intense as the signal from equivalently diluted preimmune IgY.

\section{Ostrich IgY against indicated influenza virus HA}

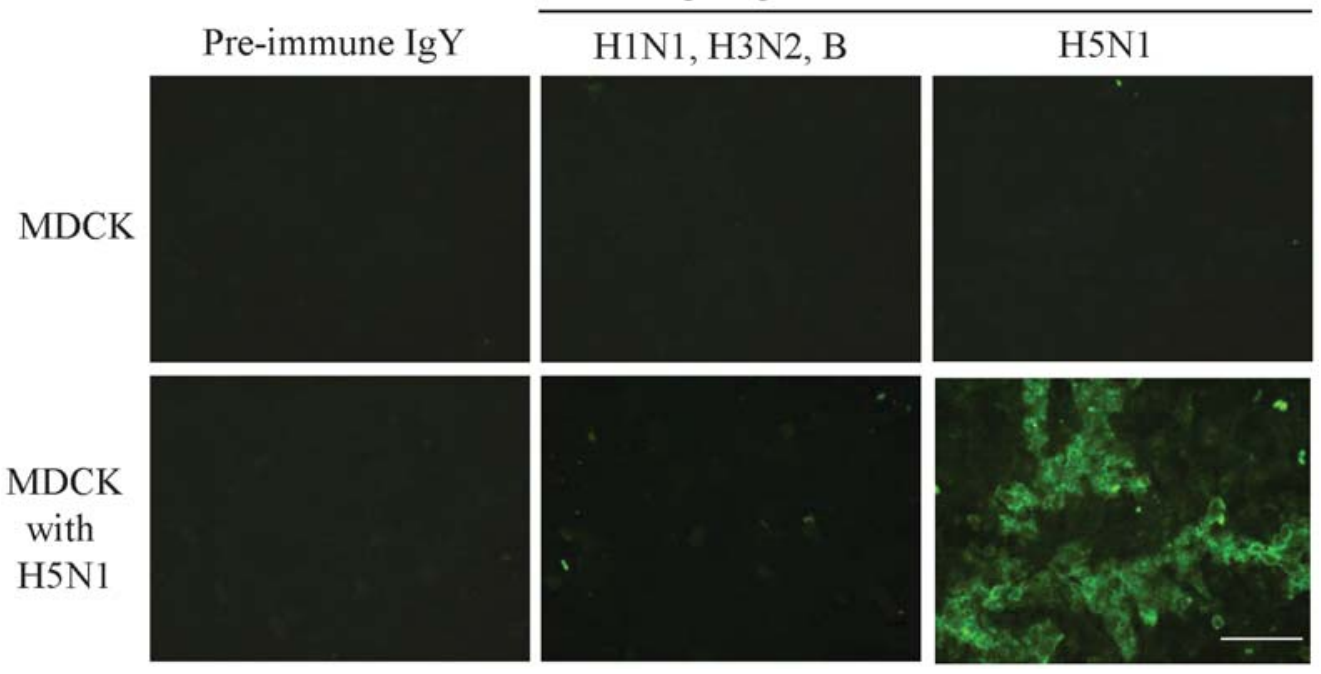

Figure 3. Immunocytochemistry of H5N1-infected MDCK cells. MDCK cells were reacted with ostrich IgY, and visualized by FITC-conjugated secondary antibody. Normal MDCK cells have no immunoreactivity to all antibodies. The H5N1-infected cells are not stained with preimmune IgY. In contrast, the cytoplasm of infected cells are stained strongly with the IgY from H5 immunized ostrich, but only slight with IgY from mixed HA (H1, H3, B) immunized bird. Bar, $50 \mu \mathrm{m}$.

more weakly to the H5N1 strain. In contrast, IgY from rH5immunized eggs reacted strongly to $\mathrm{H} 5 \mathrm{~N} 1$, but only weakly to the H1N1, H3N2 and B strains.

Next, the reactivity of ostrich IgY was examined in immunocytochemistry. MDCK cells were infected with the Indonesia strain of $\mathrm{H} 5 \mathrm{~N} 1$ and stained with antibodies. The cytoplasm of infected cells was strongly labeled with IgY from rH5-immune eggs, but not with pre-immune IgY (Fig. 3). In contrast, IgY from eggs immunized with HA from the vaccine strains showed only weak immunoreactivity to the H5N1-infected cells.

These results indicate that high titers of antibodies against the $\mathrm{H} 5 \mathrm{~N} 1$ virus are collected from eggs immunized with H5 antigens. For this reason, antibodies from the H5-hyperimmune eggs were used for further examinations.

Neutralization assays for H5N1 infection. MDCK cells and embryonated eggs were used for the neutralization assays. The H5N1 virus was reacted with serial dilutions of IgY from preimmune or rH5-immunized eggs, and neutralization was determined by the observation of CPE and embryonic death. IgY with rH5-immunization showed very strong inhibitory effects on H5N1 infection in either MDCK or chick embryos (Fig. 4 and Table II). In contrast, H5N1 infection was not blocked in either of the analyses, even at the highest concentrations of preimmune IgY, indicating no neutralization activity on the H5N1 infection.

Effect of ostrich IgY on H5N1-infected chicks. The inhibitory activity of $\mathrm{IgY}$ from rH5-immunized ostrich was examined in H5N1-infected chicks in order to elucidate the potential therapeutic uses of ostrich IgY.

A high dosage of the H5N1 Indonesian strain $\left(10^{7.9} \mathrm{TCID}_{50}\right)$ was intra-nasally challenged to 10-day-old chicks. All the birds (100\%) died by 5 -days post-inoculation and experienced severe clinical symptoms including dehydration and depression. In contrast, the mortality rate of the infected birds was dramatically decreased by the intra-muscular injection with anti-H5 IgY: only $25 \%$ of the birds died by viral infection, and the survivors had no symptoms (Fig. 5). All infected birds died when the preimmune IgY was injected instead of the rH5immune antibody. Accordingly, the anti-H5 IgY had a therapeutic effect on H5N1-infected chickens, even at the low dosage. 
A

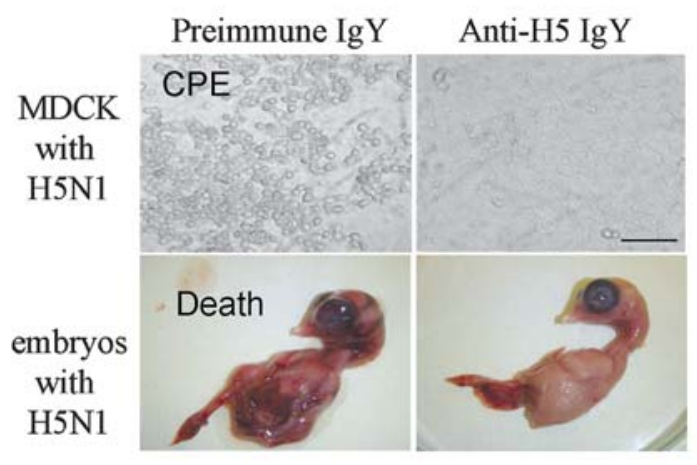

B
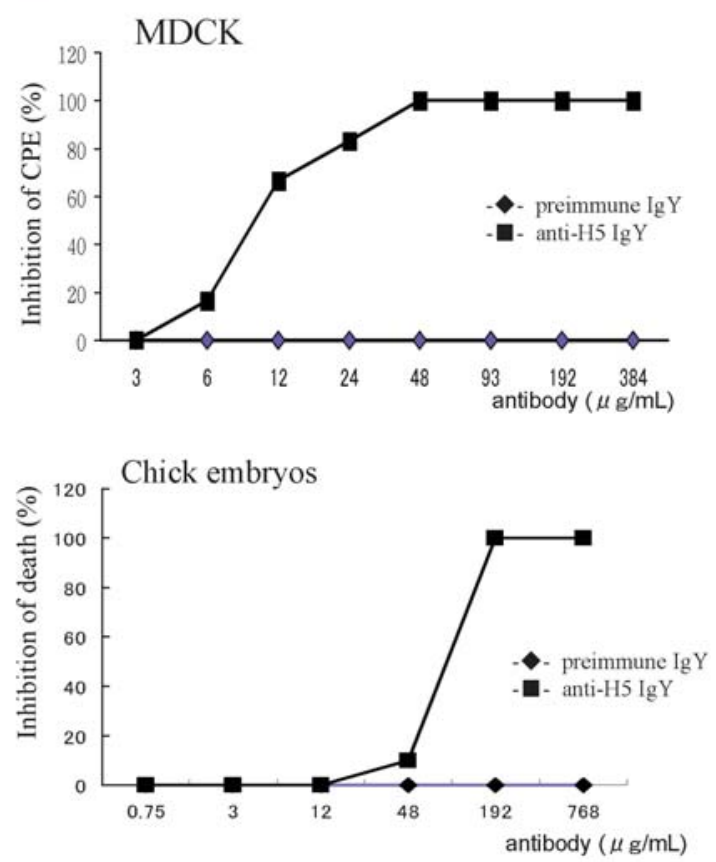

Figure 4. Neutralization activities on ostrich IgY for H5N1 infection. (A) MDCK cells infected with H5N1 virus show severe CPE on their monolayer sheet. IgY from $\mathrm{H} 5$ immunized ostrich (anti-H5 IgY) inhibit CPE, while preimmune $\mathrm{IgY}$ has no effect on the cells. Bar, $50 \mu \mathrm{m}$. (B) Neutralization activities of ostrich IgY on H5N1 infection were analyzed using MDCK cells and embryonated chick embryos. Anti-H5 IgY shows inhibitory activities on H5N1 infection in both MDCK and chick embryos, while preimmune IgY has no effect, even at the highest dosage.

Table II. Neutralizing titers of ostrich IgY against H5N1 strain.

\begin{tabular}{lcc}
\hline \multirow{2}{*}{$\begin{array}{l}\text { Antibodies against } \\
\text { indicated HA } \\
\text { antigens }\end{array}$} & $\begin{array}{c}\text { Neutralizing titers } \\
\text { MDCK cells } \\
(\mu \mathrm{g} / \mathrm{ml})\end{array}$ & $\begin{array}{c}\text { Embryonic eggs } \\
(\mu \mathrm{g} / \mathrm{ml})\end{array}$ \\
\cline { 2 - 3 } Preimmune IgY & $>384$ & $>768$ \\
rH5 & 6.7 & 63.4 \\
\hline
\end{tabular}

The neutralization assays were performed using MDCK cells and chick embryos. The neutralizing titers are indicated as the $50 \%$ inhibition on CPE or embryonic death.

\section{Discussion}

In the present study, large-scale and economical antibodies against the highly pathogenic avian influenza virus H5N1 were generated by employing the female ostrich. To do so, HA antigens were immunized to obtain neutralization antibodies. Since HA binds to the receptors and is essential for viral entrance into the host cells, these antigens are widely used in the vaccine for influenza $(17,18)$. Recently, various attempts have been made to prevent $\mathrm{H} 5 \mathrm{~N} 1$ pandemic infections $(7,19,20)$. H5 antigens are used to develop vaccines against $\mathrm{H} 5 \mathrm{~N} 1$, and therapeutic monoclonal antibodies by $\mathrm{H} 5$ vaccinations can be evaluated before the emergence of humanadapted H5N1 strains $(19,21)$.

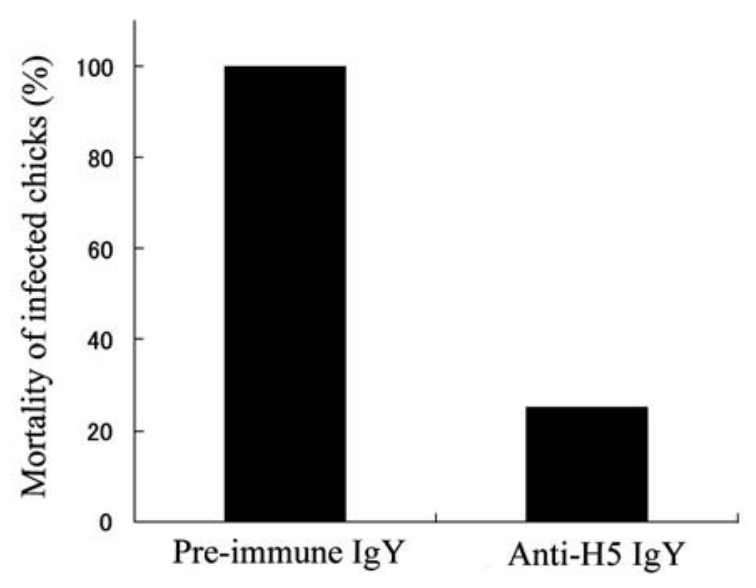

Figure 5. Effects of ostrich IgY on H5N1-infected chicks. The chicks were intra-nasally challenged with high titered $\mathrm{H} 5 \mathrm{~N} 1$ virus and infected with ostrich IgY. The dead chicks were counted at 5 days post-viral-inoculation and the mortality rate was calculated. All of infected birds died by 5 days, and preimmune IgY had no inhibitory effect on mortality. In contrast, the mortality of infected chicks was remarkably decreased by an injection with IgY from H5-immunized ostrich (anti-H5 IgY).

The HA antigens were also highly antigenic in the ostrich; we could obtain ample IgY from the female birds by immunizing them with the HA antigens of the human influenza vaccine strains of H1N1, H3N2, B and the highly pathogenic avian influenza virus H5N1. Since ostrich IgY are polyclonal, the antibodies generated with the HA of the human vaccine strains are slightly reactive to $\mathrm{H} 5$, which are likely to be raised from the homology of epitopes among these antigens.

We used the IgY from the $\mathrm{rH} 5$-immunized ostrich for neutralization and therapeutic assays against H5N1 infections, 
because this antibody had a much higher titer on the H5 antigen in comparison to other antibodies with human vaccine strains. In addition, $\mathrm{rH} 5$-immunized $\mathrm{IgY}$ was highly reactive to the H5N1-infected MDCK cells in immunocytochemistry. Therefore, this rH5-immunized IgY might be developed as a diagnostic tool for the $\mathrm{H} 5$ virus. In an ELISA against the H5 antigen, the titer of rH5-immunized IgY reached maximum levels at 8 weeks post initial immunization in the serum and yolk. The antibodies were successfully transferred from blood to yolk, which can then be non-invasively obtained by simple collection of the eggs, making it possible to obtain a high amount of anti-H5N1 antibody (200 $\mathrm{g}$ in total) from one female ostrich in a year. In neutralization assays, rH5-immunized Ig Y could inhibit H5N1 infection successfully in either MDCK cells or embryonic eggs. The H5N1 virus is highly virulent to chick embryos and it is difficult to protect them from virus infection using antibodies. However, in the present study ostrich IgY could inhibit H5N1 infection even in the embryos, although the volume of antibodies needed for viral protection was larger in embryos than in MDCK cells.

For the protection of poultry, neutralizing antibodies to HA and neuraminidase proteins have been reported to provide primary protection against the highly pathogenic avian influenza (22). In addition, the prophylactic and therapeutic efficacy of human monoclonal antibodies was elucidated by the H5N1 infections (21). One particularly interesting and potentially important finding of the present study was the observation that the chicks were protected by a low dosage of $\mathrm{H} 5$ immunized $\mathrm{IgY}$ from the H5N1 infection. This finding leads to the potential development of ostrich IgY for therapeutic treatment against an $\mathrm{H} 5 \mathrm{~N} 1$ pandemic. For the protection of poultry, a neutralizing antibody to the hemagglutinin and neuraminidase proteins provides the primary protection against the highly pathogenic avian influenza. It has been reported that chicken IgY has been used for therapeutic purposes: IgY preparations are administrated to patients suffering from infectious diseases including rotaviruses, enterotoxigenic Escherichia coli, coronavirus, Salmonella spp., Edwardsiella tarda, Yersinia ruckeri, Staphilococcus and Pseudomonas $(23,24)$. Therefore, we believe that ostrich $\operatorname{IgY}$ is a promising alternative to antibiotics for passive immunotherapy application as well as for chicken antibody.

Because most of the human population has no immunity to $\mathrm{H} 5 \mathrm{~N} 1$, the most effective method for the reduction of the impact of a pandemic has been reported to be prophylaxis with a safe and effective vaccine (6). In addition, anti-viral materials are recommended for the prevention of an influenza pandemic (8). In this study, a large amount of neutralization antibodies against $\mathrm{H} 5 \mathrm{~N} 1$ were produced with cost effectiveness, which indicates the potential use of ostrich antibody for industrial purposes, thus including the development of anti-viral materials. It is speculated that the $\operatorname{IgY}$ on the filters can capture the viral particles of $\mathrm{H} 5 \mathrm{~N} 1$ by antigen-antibody reactions, so the virus would be trapped by the filters and not pass through them. In addition, the virus might be neutralized on the filters, because HA is masked with IgY and cannot enter host cells. In the preliminary study, we found that the infectivity of H5N1 was dramatically decreased by the filters adsorpted with ostrich IgY generated by H5 immunizations (data not shown). We are now attempting to apply the ostrich
IgY onto masks of either the N95 or surgical type to protect humans from an influenza pandemic caused by the H5N1 virus. In the event of such a pandemic, where effective vaccine and antiviral medicines may be lacking, disrupting the environmental transmission of the $\mathrm{H} 5 \mathrm{~N} 1$ virus will be the only viable strategy for the protection of the people. We believe that filters impregnated with ostrich antibodies will be a powerful tool for protection against the influenza pandemic.

\section{Acknowledgements}

The authors thank Drs Saeko Morikawa, Satoshi Hiroi, Takahiro Yumisashi and Tetsuo Kase at the Osaka Prefectural Institute of Public Health for their helpful comments. This study was supported in part by Research Fellowships from the Japan Society for the Promotion of Science (Nos. 17688013 and 18658115) and by an innovation grant from the Japan Science and Technology Agency (JST; No. 1804).

\section{References}

1. McCauley JW, Pullen LA, Forsyth M, Penn CR and Thomas GP: 4-Guanidino-Neu5Ac2en fails to protect chickens from infection with highly pathogenic avian influenza virus. Antiviral Res 27: 179-186, 1995.

2. Alexander DJ and Brown IH: Recent zoonoses caused by influenza A viruses. Rev Sci Tech 19: 197-225, 2000.

3. Rimmelzwaan GF and Osterhaus AD: Influenza vaccine: new developments. Curr Opin Pharmacol 1: 491-496, 2001.

4. Normile D: North Korea collaborates to fight bird flu. Science 308: 175, 2005.

5. Leroux-Roels I, Borkowski A, Vanwolleghem T, Drame M, Clement F, Hons E, Devaster JM and Leroux-Roels G: Antigen sparing and cross-reactive immunity with an adjuvanted rH5N1 prototype pandemic infl uenza vaccine:a randomised controlled trial. Lancet 370: 580-589, 2007.

6. Poland GA: Vaccines against avian influenza - a race against time. N Engl J Med 354: 1411-1413, 2006.

7. Sharpe M, Lynch D, Topham, Major D, Wood J and Loudon P: Protection of mice from H5N1 influenza challenge by prophylactic DNA vaccination using particle mediated epidermal delivery. Vaccine 25: 6392-6398, 2007.

8. CDC: Experiences with influenza-like illness and attitude regarding influenza prevention - United States, 2003-04 influenza season. MMWR 53: 1156-1158, 2004.

9. Schade R, Pfister C, Halatsch R and Henklein P: Polyclonal IgY antibodies from chicken egg yolkóan alternative to the production of mammalian IgG type antibodies in rabbits. ATLA 19: 403-419, 1991.

10. Schade R, Schniering A and Hlinak A: Polyclonal avian antibodies extracted from egg yolk as an alternative to the production of antibodies in mammals - a review. ALTEX 9: 43-56, 1992.

11. Gross M and Speck J: Avian yolk antibodies in diagnosis and research. Dtsch Tierarztl Wochenschr 103: 417-422, 1996.

12. Larsson A, Balow RM, Lindahl TL and Forsberg PO: Chicken antibodies: taking advantage of evolution-a review. Poult Sci 72: $1807-1812,1993$.

13. Leslie GA and Clem LW: Phylogeny of immunoglobulin structure and function. III. Immunoglobulins of the chicken. J Exp Med 130: 1337-1352, 1969.

14. Adachi K, Hagimori K, Kato H, Fukuda K, Kikuta M and Tsukamoto Y: Potential role of SC1, a cell adhesion molecule, in mammary gland tumors. Mol Med Rep (In press).

15. Reed LJ and Muench H: A simple method of estimating fifity percent end-points. Am J Hyg 27: 493-797, 1938.

16. Lu L, Yu L and Kwang J: Baculovirus surface-displayed hemagglutinin of H5N1 influenza virus sustains its authentic cleavage, hemagglutination activity, and antigenicity. Biochem Biophys Res Commun 358: 404-409, 2007.

17. Bosch FX, Orlinch M, Klenk HD and Rott R: The structure of the hemagglutinin, a determinant for the pathogenicity of influenza viruses. Virology 95: 197-207, 1979. 
18. Takada A, Kuboki N, Okazaki K, Ninomiya A, Tanaka H, Ozaki H, Itamura S, Nishimura H, Enami M, Tashiro M, Shortridge KF and Kida H: A virulent avian influenza virus as a vaccine strain against a potential human pandemic. J Virol 73: 8303-8307, 1999.

19. Yang ZY, Wei CJ, Kong WP, Wu L, Xu L, Smith DF and Nabel GJ: Immunization by avian H5 influenza hemagglutinin mutants with altered receptor binding specificity. Science 317 : 825-828, 2007.

20. Kistner O, Howard OK, Spruth M, Wodal W, Bruhl P, Gerencer M, Crowe BA, Savidis-Dacho H, Livey I, Reiter M, Mayerhofer I, Tauer C, Grillberger L, Mundt W, Falkner FG and Barrett PN: Cell culture (Vero) derived whole virus (H5N1) vaccine based on wild-type virus strain induces cross-protective immune responses. Vaccine 25: 6028-6036, 2007.
21. Simmons CP, Bernasconi NL, Suguitan JAL, Mills K, Ward JM, Chau NVV, Tran Tinh, Hien TT, Sallusto F, Ha DQ, Farrar J, De-Jong MD, Lanzavecchia A and Subbarao K: Prophylactic and therapeutic efficacy of human monoclonal antibodies against H5N1 influenza. PLoS Med 4: 928-936, 2007.

22. Suarez DL and Schultz-Cherry S: Immunology of avian influenza virus: a review. Dev Comp Immunol 24: 269-283, 2000.

23. Mine Y and Kovacs-Nolan J: Chicken egg yolk antibodies as therapetutics in enteric infectious disease: a review. J Med Food 5: 159-169, 2002.

24. Carlander D, Olesen H, Kollberg H, Johannesson M, Wejaker PE and Larsson A: Oral administration of specific yolk antibodies (IgY) may prevent Pseudomonas aeruginosa infections in patients with cystic fibrosis: A phase I feasibility study. Pediatr Pulmonol 35: 433-440, 2003. 